\title{
Experimental infection of Flavobacterium psychrophilum in fins of Atlantic salmon Salmo salar revealed by scanning electron microscopy
}

\author{
Juan Luis Martínez ${ }^{1, *}$, Alín Casado ${ }^{2}$, Ricardo Enríquez ${ }^{2}$ \\ ${ }^{1}$ Departamento de Biología de Organismos y Sistemas, Universidad de Oviedo, c/ Catedrático Rodrigo Uría s/n, 33071 Oviedo, Spain \\ ${ }^{2}$ Laboratorio de Ictiopatología, Facultad de Ciencias Veterinarias, Universidad Austral de Chile, Valdivia, Chile
}

\begin{abstract}
Infections caused by Flavobacterium psychrophilum include 'bacterial coldwater disease' (BCWD) and 'rainbow trout fry syndrome' (RTFS), which are severe diseases that can cause high mortality and significant losses in hatchery-reared salmonids worldwide. Usually, these conditions start with necrosis along the edge of the fins. As the infection progresses, both the fish surface and the internal organs can be involved. The aetiological agent produces a Ca-dependent protease that can be responsible for some of the pathogenic responses, although the precise nature of the response remains to be elucidated. Atlantic salmon Salmo salar were experimentally infected by $F$. psychrophilum in order to investigate the bacterial invasion in the fin tissues by scanning electron microscopy. The images showed numerous bacteria embedded in the mucous layer when this remained on the tegument. In other zones without mucus, it was observed that bacteria were present on the axis of fin rays, but not on the epidermal surface. The material on these axes was largely eroded by tubular boreholes, and bacterial rods could be seen in these perforations. EDX (Energy Dispersive X-ray) microanalysis of the axis of the fin rays showed significant amounts of $\mathrm{P}$ and $\mathrm{Ca}$, revealing the ossification of the ray axis. The protease activity could explain the formation of the tubular boreholes, allowing the bacteria the necessary Ca for the activation of the enzyme. The erosion pattern suggests that the gliding motility of $F$. psychrophilum could be involved in this burrowing ability.
\end{abstract}

KEY WORDS: Flavobacterium psychrophilum · Scanning electron microscopy · Salmonid · Fin rays · Pathogenesis · Bacterial coldwater disease (BCWD) · Rainbow trout fry syndrome (RTFS)

Resale or republication not permitted without written consent of the publisher

\section{INTRODUCTION}

Flavobacterium psychrophilum (formerly Cytophaga psychrophila and Flexibacter psychrophilus) (Bernardet et al. 1996) is the aetiological agent of the diseases referred to as 'bacterial cold water disease' (BCWD) (Wood \& Yasutake 1956) and 'rainbow trout fry syndrome' (RTFS) (Austin \& Stobie 1991), also called 'fry mortality syndrome' (Lorenzen et al. 1991) and 'rainbow trout fry anaemia' (RTFA) (Bruno \& Poppe 1996). These are septicaemic infections that are particularly serious in juvenile fish that are not fully immunocompetent. Severe outbreaks with significant early losses have been reported in hatchery-reared salmonids world-wide, particularly rainbow trout Oncorhynchus mykiss in Europe and coho salmon O. kisutch in America, but several non-salmonid fish species have also been affected (Dalsgaard 1993, Nematollahi et al. 2003a). Eyed (Rangdale et al. 1997) and unfertilised eggs (Vatsos et al. 2001) likewise were infected. Currently, F. psychrophilum is well characterised by different genetic and molecular techniques that differ- 
entiate this species from other closely related bacteria found in diseased salmonid fish (Crump et al. 2001, Bader \& Starliper 2002, del Cerro et al. 2002).

Although Flavobacterium psychrophilum is responsible for a wide range of conditions of the external (and occasionally internal) tissues of the fish, early signs mainly affect the fins as a line of whitish material along the margin. Fin rays may also begin to separate, and the disease progresses inwardly on the fins until the base of the attachment of the fins is reached (Shotts \& Starliper 1999, Bader \& Starliper 2002).

Characteristics of Flavobacterium psychrophilum have caused difficulties in challenge methods with the bacteria (Decostere et al. 2000), but successful attempts at experimentally inducing the disease have been reported, and several methods have been described, such as intraperitoneal, subcutaneous or intramuscular injections, baths, and patches on the skin (Madsen \& Dalsgaard 1999, Garcia et al. 2000, Ekman 2003). The precise nature of the pathogenic mechanism of F. psychrophilum is poorly understood, but since Pacha (1968) postulated that the proteolytic nature of the bacteria plays a part in the mode of pathogenesis, an important role for extracellular proteases produced by the bacteria has been recognised (Otis 1984, Madsen \& Dalsgaard 1998, Crump et al. 2001, Secades et al. 2001).

Kondo et al. (2002) showed the adherence of Flavobacterium psychrophilum on the surface of the ayu Plecoglossus altivelis, and Rangdale et al. (1999) histopathologically and ultrastructurally examined the spleen in cases of rainbow trout fry syndrome, but no electron microscopical study was made to analyse the features of the F. psychrophilum infection in salmonid fins. In this study, Atlantic salmon Salmo salar were experimental infected by F. psychrophilum, and their fins observed by scanning electron microscopy (SEM) in order to investigate the invasion of bacteria in the tissue.

\section{MATERIALS AND METHODS}

Bacterial cultivation and preparation. Flavobacterium psychrophilum Strain R.128 was originally isolated at the Ichthyopathology Laboratory (Universidad Austral de Chile) from diseased fish displaying characteristic signs of RTFS. Bacteria were grown in modified Anacker and Ordal agar (MAOA) (0.5\% typtone, $0.05 \%$ yeast extract, $0.02 \%$ sodium acetate, $0.02 \%$ beef extract, $1.5 \%$ agar) (Lorenzen et al. 1997) at $15^{\circ} \mathrm{C}$ for $3 \mathrm{~d}$ and washed twice in PBS pH 7.2 centrifuged at 4000 rpm $(2021 \times g)$ for $20 \mathrm{~min}$. The bacterial solution prepared for experimental infection was $3.3 \times 10^{8}$ colony forming units (CFU) $\mathrm{ml}^{-1}$ in a total volume of $30 \mathrm{ml}$.
Fish and experimental infection. Juvenile Atlantic salmon Salmo salar, $\mathrm{n}=30$, initial mean weight $17.3 \mathrm{~g}$, were obtained from a hatchery, transferred to the Ichthyopathology Laboratory and controlled in accordance with the O.I.E procedures (OIE 1997). Fish were randomly separated into 2 groups. Subsequently, one group was immersed for $1 \mathrm{~h}$ in an aquarium with $3 \mathrm{l}$ of freshwater at $15^{\circ} \mathrm{C}$ containing Flavobacterium psychrophilum at a final concentration of $3.3 \times 10^{6} \mathrm{CFU}$ $\mathrm{ml}^{-1}$. The other group, control fish, was introduced to a similar aquarium with $3 \mathrm{l}$ of freshwater at $15^{\circ} \mathrm{C}$ (in the absence of bacteria). Each group was afterwards moved to 801 freshwater aquariums.

Sampling procedure. In the exposed group, samples were obtained at 0,24 , and $48 \mathrm{~h}$ post infection times (PIT). Three fish of each PIT group were sacrificed and the dorsal fins were removed. In one sample of each PIT group, the tips of the fin rays were cut off with a scalpel. Likewise, samples were obtained from control fish. The samples were fixed in Karnowsky fixative (2.5\% glutaraldehyde, $4 \%$ paraformaldehyde and $0.1 \mathrm{M}$ sodium cacodylate buffer $\mathrm{pH}$ 7.2) for $72 \mathrm{~h}$ at room temperature and dehydrated in ethanol. They were then immediately desiccated in liquid $\mathrm{CO}_{2}$ with a critical point drier (Hitachi HCP-2), and coated with palladium-gold in a sputter coater (Eiko IB-2). Finally, the samples were studied in a scanning electron microscope (Leo-420).

Chemical microanalysis by Energy Dispersive X-ray (EDX). In order to analyse their chemical composition, rays were excised from dorsal fins of healthy fish, and mechanically scraped to remove the external soft tegument. The rays were dried in an oven, mounted in stubs, carbon coated in a Polaron CC7650, and observed in a JEOL-6100 scanning electron microscope with EDX microanalysis. Two types of measurements were taken: (1) microanalysis at a point, (2) microanalysis of the average values in an area.

\section{RESULTS}

\section{Experimental infection}

Experimental infection was successful. Although external lesions were not conspicuous in the studied post-infection times, SEM observation showed the presence of bacteria in fish tissues, as described below.

\section{SEM observation}

In samples where fin rays were not cut, they were covered by a mucous layer embedding the bacteria (Fig. 1). 


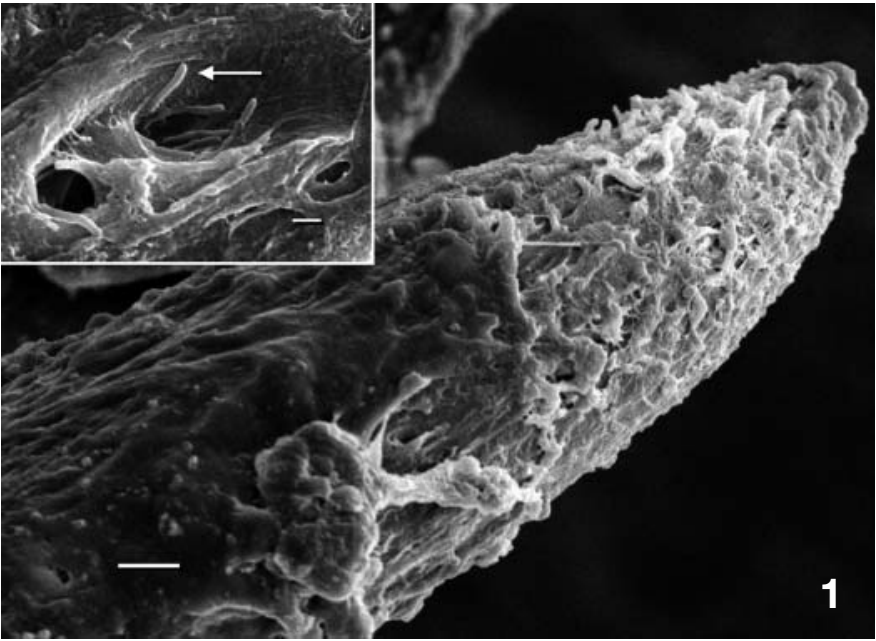

Fig. 1. Salmo salar. Uncut ray of the dorsal fin coated by a dense mucous layer. Post infection time (PIT): $0 \mathrm{~h}$. Scale bar $=10 \mu \mathrm{m}$. Insert: Flavobacterium psychrophilum rods (arrow) embedded in mucus. PIT: 0 h. Scale bar $=1 \mu \mathrm{m}$

Flavobacterium psychrophilum were rod shape, up to $2 \mu \mathrm{m}$ in length and $0.4 \mu \mathrm{m}$ in width.

In samples where fin rays were cut immediately before chemical fixation, the tegument appeared to be retracted in the basal zone, and the fin axis was naked and lacking a mucous layer (Fig. 2). In these cases, a large number of bacteria on the hard material of the fin axis could be observed, while none were found on the retracted epidermis. High magnifications of SEM images showed some of the bacteria lying on the material axis, and apparently penetrating directly into the substrate (Fig. 3).

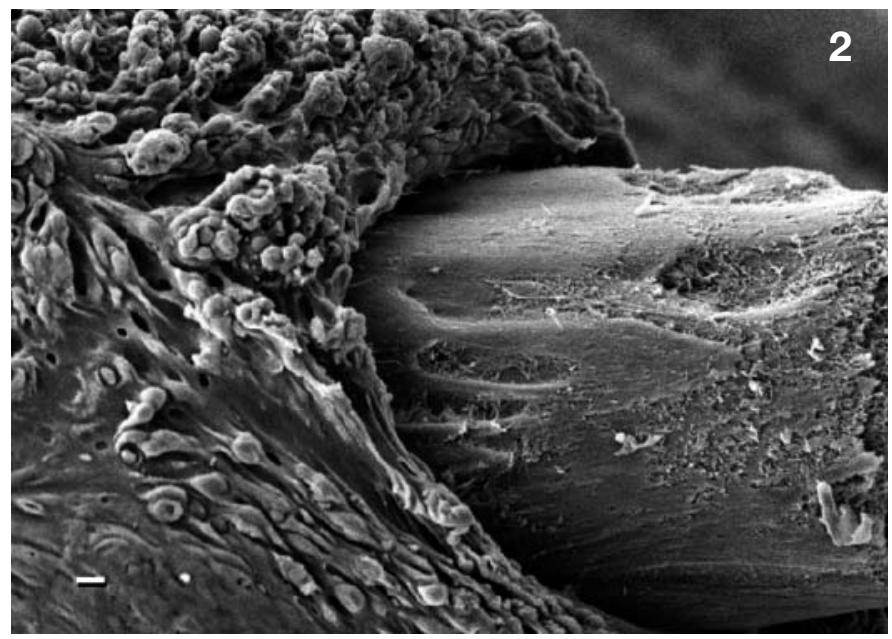

Fig. 2. Salmo salar. Ray cut immediately before fixation. The tegument appears withdrawn to the base of the ray. Numerous Flavobacterium psychrophilum bacteria can be seen on the ray axis (see Fig. 3), but not on the epidermis. PIT: 48 h. Scale bar $=10 \mu \mathrm{m}$

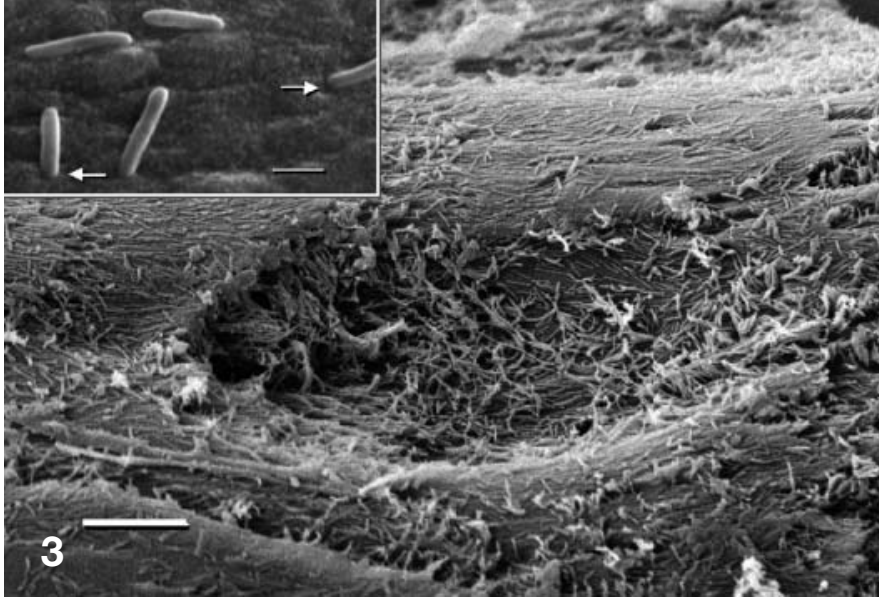

Fig. 3. Flavobacterium psychrophilum bacteria spreading on the surface of the Salmo salar ray axis of the dorsal fin. PIT: $48 \mathrm{~h}$. Scale bar $=10 \mu \mathrm{m}$. Insert: Rods of $F$. psychrophilum on the naked axis of the ray. Some of them seem to be penetrating into the substrate (arrows). PIT: $24 \mathrm{~h}$. Scale bar $=1 \mu \mathrm{m}$

In samples of 24 or $48 \mathrm{~h}$ PIT, the ray axis was fully eroded by grooves and tubular boreholes whose dimensions corresponded to that of Flavobacterium psychrophilum. Bacterial rods could be seen in these perforations (Fig. 4).

\section{Chemical microanalysis by EDX}

Rays from dorsal fin were segmented and occasionally bifurcated (Fig. 5). EDX microanalysis of the ray axes showed that they were mineralised. Both in punc-

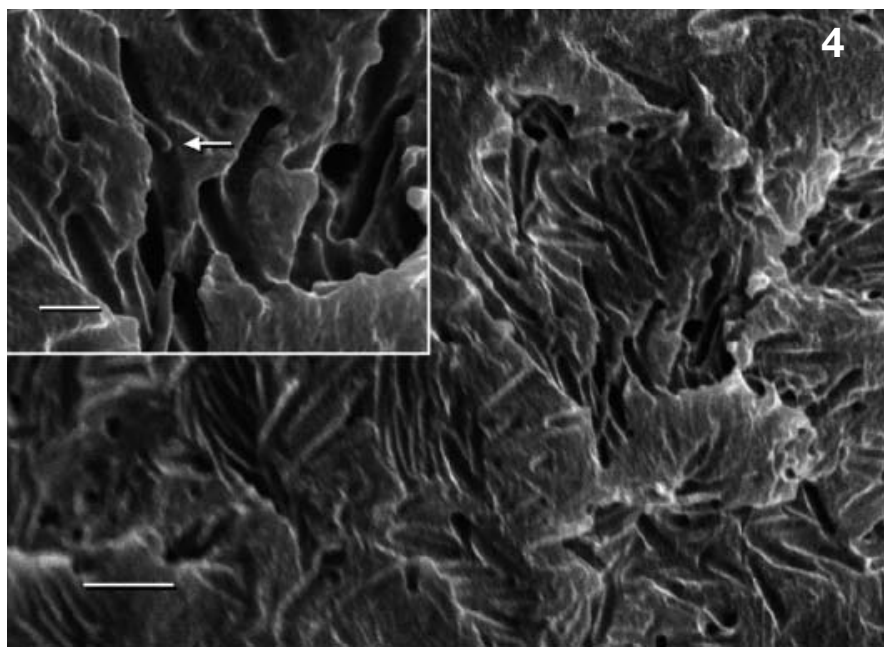

Fig. 4. Surface of a Salmo salar ray axis eroded by tubular grooves and boreholes of circular section. PIT: $24 \mathrm{~h}$. Scale bar $=3 \mu \mathrm{m}$. Insert: Note the presence of bacterial rods in the grooves (arrow). PIT: $24 \mathrm{~h}$. Scale bar $=1 \mu \mathrm{m}$ 


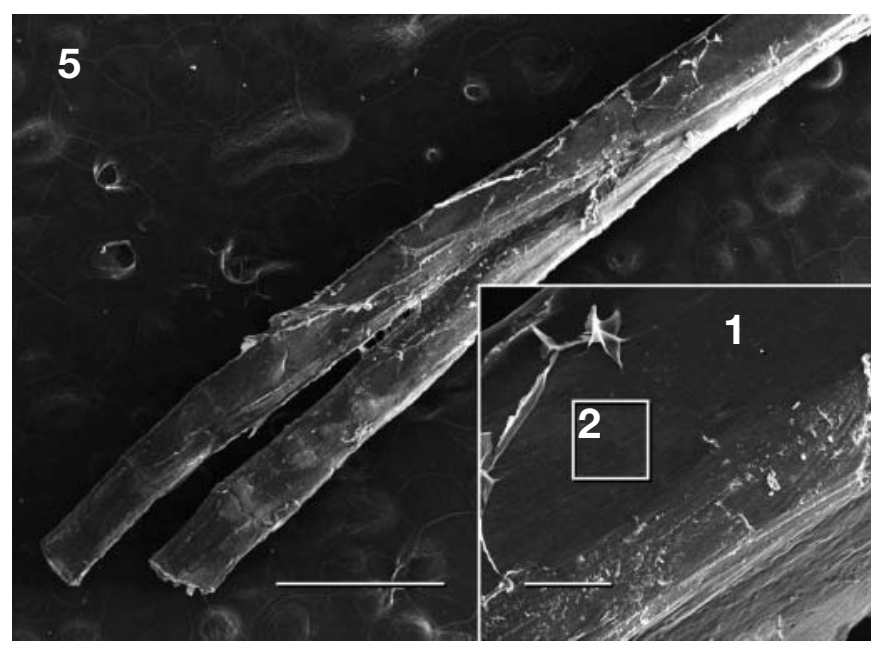

Fig. 5. Bifurcated ray of the Salmo salar dorsal fin. Segments can be seen in the distal tip (left). The ray was excised and scraped to remove the external soft tissues. Scale bar $=1 \mathrm{~mm}$. Insert: Point (1) and Area (2) of the ray axis where EDX (Energy Dispersive X-ray) microanalyses were carried out. Scale bar $=100 \mu \mathrm{m}$

tual and area measurements (Fig. 5), the spectra showed the presence of significant amounts of $\mathrm{Ca}$ (18.18 and 16.54 in atomic percent, respectively) and $\mathrm{P}$, besides $\mathrm{C}$ and $\mathrm{O}$ (corresponding to organic substances, in general) and traces of Mg and $\mathrm{S}$ (Fig. 6).

\section{DISCUSSION}

SEM images showed that bacteria spread on the naked axis of the fin but were absent on the adjacent epidermis. This suggests that Flavobacterium psychrophilum shows a preference in choice of substrate, which had not been reported in previous studies. Kondo et al. (2002) noted that F. psychrophilum adhered to the comb-like teeth of infected ayu Plecoglossus altivelis and also to the lower jaw and caudal peduncle, where the epidermis tissue collapsed, but from their SEM images direct contact of bacteria with the hard tissues was not observed. Nematollahi et al. (2003b) showed adherence properties of F. psychrophilum to the gill arch of rainbow trout Oncorhynchus mykiss but no electron microscopic images were presented.

Flavobacterium psychrophilum usually only invades previously damaged tissue, typically an area of erosion on the edge of the fins and tail. Infection then progresses to involve the complete fin or tail and caudal peduncle (Southgate 1993, Shotts \& Starliper 1999). This interpretation seems to be in agreement with the SEM images, which suggest that the integrity of the ray tip plays an important role in protection against $F$. psychrophilum invasion. As long as the epidermis and a thick mucous layer covered the tips, the bacteria had difficulty accessing the ray axis. Any factor (mechanical or physiological) altering the integrity of that covering will allow the bacteria to reach the ray axis, which is the preferred substrate. This would also explain how the stress imposed by management methods undoubtedly predisposes hatchery-raised fish to such infections (Anderson \& Conroy 1969). Mechanical injury of the fins has been indicated as a plausible entrance for F. psychrophilum into the fish, and it has been experimentally demonstrated that skin and skin mucus abrasion dramatically enhance the invasion of bacteria (Madetoja et al. 2000). In the later stages of disease, bacteria also destroy the skin and other tissues, affecting internal organs (Wood \& Yasutake 1956, Noga 1996, Shotts \& Starliper 1999), but SEM images seem to indicate that in the initial phase of the process, the first substrate affected is the ray axis. In advanced cases, or in recovered fish, bone diseases often develop: scoliosis, cranial and vertebral lesions including subacute to chronic periostitis and ostitis, cephalic osteochondritis and necrotic scleritis, or inflammation and cartilage necrosis along the vertebral column (Dalsgaard 1993, Bruno \& Poppe 1996, Ostland et al. 1997, Shotts \& Starliper 1999, Bader \& Starliper 2002). Affected fish may

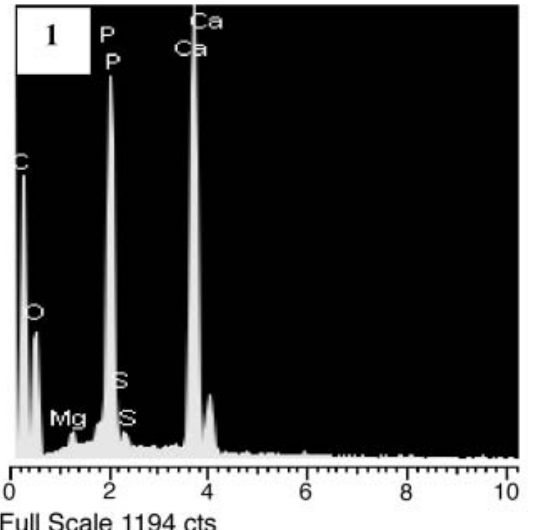

Full Scale 1194 cts

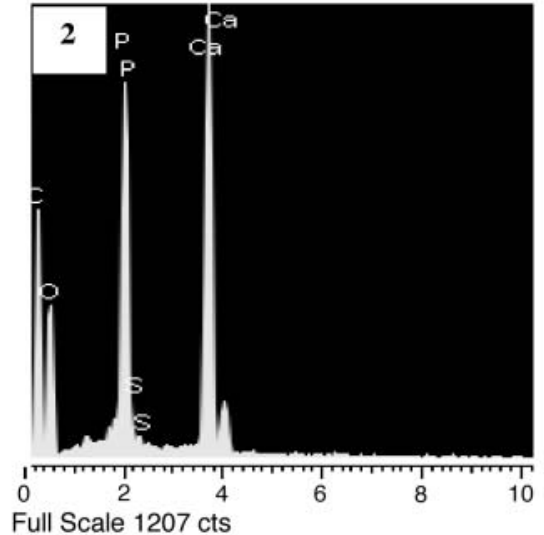

\begin{tabular}{ccccccc} 
Spectrum & O & Mg & P & S & Ca & Total \\
\hline 1 & 67.62 & 0.73 & 12.74 & 0.74 & 18.18 & 100 \\
2 & 71.13 & & 11.90 & 0.43 & 16.54 & 100 \\
\multicolumn{5}{c}{ All results in Atomic Percent } \\
\end{tabular}

Fig. 6. Results of the EDX (Energy Dispersive X-ray) microanalysis in Point (1) and Area (2) (see Fig. 5) tested on the ray axis of the Salmo salar fin. Both spectra show a significant amount of $\mathrm{Ca}$ and $\mathrm{P}$, besides $\mathrm{C}$ and $\mathrm{O}$ and traces of $\mathrm{Mg}$ and $\mathrm{S}$. cts: $\mathrm{cm}$ 
also develop neurological diseases, ataxia and abnormal swimming behaviour, presumably from the localisation of bacteria in the cranium (Noga 1996, Bader \& Starliper 2002).

SEM images showed bacteria covered with mucus. Bacteria may be destroyed by antimicrobial products (lysozymes, complement, agglutinins) present in the mucus (Ellis 1981, Alexander 1985, Yano 1996, Lebedeva 1999), but Denkin \& Nelson (1999) also demonstrated that growth or incubation of Vibrio anguillarum in salmon intestinal mucus rapidly and specifically induced protease activity. Extracellular proteases have been shown to be virulence factors for a variety of bacteria, including Flavobacterium psychrophilum (Pacha 1968, Otis 1984, Dalsgaard 1993, Bertolini et al. 1994, Ostland et al. 2000), and they participate in tissue damage to the host. The formation of grooves and tubular boreholes observed by SEM in the ray axis may be explained by the effect of products secreted by the bacteria. Secades et al. (2001) purified and characterised an extracellular protease from F. psychrophilum, designated Fpp1, which was found to be a $55 \mathrm{kDa}$ psychrophilic protein and a potent enzyme with broad specificity for degrading protein constituents of connective and muscular tissues. This suggests that it participates in pathogenesis by contributing to colonisation and/or invasion of the fish tissues. Moreover, the authors showed that the presence of calcium was necessary for Fpp1 production. The EDX microanalysis showed the presence of high amounts of $\mathrm{Ca}$ and $\mathrm{P}$ in the ray axis, confirming the latter's mineralised nature. This suggests that F. psychrophilum could digest the substrate with the metalloprotease, and simultaneously it could obtain from the substrate the necessary $\mathrm{Ca}$ for the activation of the enzyme. This could be the reason for the preference that bacteria show for the fin rays in early phases of the infection.

The effect of proteases released by the bacteria is a uniform digestion of the substrate. Nevertheless, the SEM images showed more individualised effects, appearing as tubular perforations of dimensions similar to rods of Flavobacterium psychrophilum, which seems to indicate that the enzyme has a short operational range. The perforations appear as circular orifices, indicating that movement of the bacteria is perpendicular to the surface. The results suggest the existence of a mechanical perforation working in conjunction with the substrate degradation produced by the chemical processes. The gliding motility, characteristic of this group of bacteria and defined as the movement of a non-flagellated cell in the direction of its long axis on a surface (Henrichsen 1972), would play a role in producing the observed pattern of perforation. Several models for gliding have been proposed for different organisms, including, among others, rotary motors (Pate \& Chang 1979), directional extrusion of slime (Hoiczyk \& Baumeister 1998) and controlled release of surfactants from poles of cells (Keller et al. 1983). In Cytophaga sp., during gliding in either the forward or reverse direction, cells were observed entering into abrupt clockwise and counterclockwise rotations around either cell pole (Lapidus \& Berg 1982), and the entire length of the cell body was rarely seen in contact with the substratum (Godwin et al. 1989). Whether or not the characteristics of bacterial movement are implicated in the type of perforation observed in the fin rays cannot be determined from SEM images alone.

Acknowledgements. We thank R. Silva and C. Lizama of the Facultad de Medicina (Universidad Austral de Chile) for technical assistance in the processing of SEM samples. This work was made possible by a grant of AECI (Agencia Española de Cooperación Internacional) to J.L.M.

\section{LITERATURE CITED}

Alexander JB (1985) Non-immunoglobulin humoral defense mechanisms in fish. In: Manning MJ, Tatner MF (eds) Fish immunology. Academic Press, London, p 133-140

Anderson JI, Conroy DA (1969) The pathogenic myxobacteria with special reference to fish diseases. J Appl Bacteriol 32:30-39

Austin B, Stobie M (1991) Recovery of yellow pigmented bacteria from dead and moribund fish durin outbreaks of rainbow trout, Oncorhynchus mykiss (Walbaum), fry syndrome in England. J Fish Dis 14:677-682

Bader JA, Starliper CE (2002) The genera Flavobacterium and Flexibacter. In: Cunningham CO (ed) Molecular diagnosis of salmonid diseases. Kluwer Academic Publishers, Dordrecht, p 99-139

Bernardet JF, Segers P, Vancanneyt M, Berthe F, Kersters K, Vandamme P (1996) Cutting a gordian knot: emended classification and description of the genus Flavobacterium, emended description of the family Flavobacteriaceae, and proposal of Flavobacterium hydatis nom.nov. (basonym, Cytophaga aquatilis Strohl and Tait 1978). Int J Syst Bacteriol 46:128-148

Bertolini JM, Wakabayashi H, Watral VG, Whipple MJ, Rohovec JS (1994) Electrophoretic detection of proteases from selected strains of Flexibacter psychrophilus and assessment of their viability. J Aquat Anim Health 6: 224-233

Bruno DW, Poppe TT (1996) A colour atlas of salmonid diseases. Academic Press, London

Crump EM, Perry MB, Clouthier SC, Kay WW (2001) Antigenic characterization of the fish pathogen Flavobacterium psychrophilum. Appl Environ Microbiol 67:750-759

Dalsgaard I (1993) Virulence mechanisms in Cytophaga psychrophila and other Cytophaga-like bacteria pathogenic for fish. Annu Rev Fish Dis 3:127-144

Decostere A, Lammens M, Haesebrouck F (2000) Difficulties in experimental infection studies with Flavobacterium psychrophilum in rainbow trout (Oncorhynchus mykiss) using immersion, oral and anal challenges. Res Vet Sci 69:165-169 
del Cerro A, Marquez I, Guijarro JA (2002) Simultaneous detection of Aeromonas salmonicida, Flavobacterium psychrophilum, and Yersinia ruckeri, three major fish pathogens, by multiplex PCR. Appl Environ Microbiol 68:5177-5180

Denkin SM, Nelson DR (1999) Induction of protease activity in Vibrio anguillarum by gastrointestinal mucus. Appl Environ Microbiol 65:3555-3560

Ekman E (2003) Natural and experimental infections with Flavobacterium psychrophilum in salmonid fish. $\mathrm{PhD}$ thesis, Swedish University of Agricultural Sciences, Uppsala

Ellis AE (1981) Non-specific defense mechanisms in fish and their role in disease processes. Dev Biol Stand 49:337-352

Garcia C, Pozet F, Michel C (2000) Standardization of experimental infection with Flavobacterium psychrophilum, the agent of rainbow trout Oncorhynchus mykiss fry syndrome. Dis Aquat Org 42:191-197

Godwin SL, Fletcher M, Burchard RP (1989) Interference reflection microscopic study of sites of association between gliding bacteria and glass substrata. J Bacteriol 171: 4589-4594

Henrichsen J (1972) Bacterial surface translocation: survey and a classification. Bacteriol Rev 36:478-503

Hoiczyk E, Baumeister W (1998) The junctional pore complex, a prokaryotic secretion organelle, is the mollecular motor underlying gliding motility in cyanobacteria. Curr Biol 8: $1161-1168$

Keller KH, Grady M, Dworkin M (1983) Surface tension gradient: feasible model for gliding motility of Myхососcus xanthus. J Bacteriol 155:1358-1366

Kondo M, Kawai K, Kurohara K, Oshima S (2002) Adherence of Flavobacterium psychrophilum on the body surface of the ayu Plecoglossus altivelis. Microb Infect 4:279-283

Lapidus IR, Berg HC (1982) Gliding motility of Cytophaga sp. strain U67. J Bacteriol 151:384-398

Lebedeva NY (1999) Skin and superficial mucus of fish: biochemical structure and functional role. In: Saksena DN (ed) Ichthyology. Recent research advances. Oxford \& IBH Publishing, New Delhi, p 177-193

Lorenzen E, Dalsgaard I, From J, Hansen EM, Horlyck V, Korsholm H, Mellergaard S, Olesen NJ (1991) Preliminary investigations of fry mortality syndrome in rainbow trout. Bull Eur Assoc Fish Pathol 11:77-79

Lorenzen E, Dalsgaard I, Bernardet JF (1997) Characterization of isolates of Flavobacterium psychrophilum associated with coldwater disease or rainbow trout fry syndrome. I: phenotypic and genomic studies. Dis Aquat Org 31:197-208

Madetoja J, Nyman P, Wiklund T (2000) Flavobacterium psychrophilum, invasion into and shedding by rainbow trout Oncorhynchus mykiss. Dis Aquat Org 43:27-38

Madsen L, Dalsgaard I (1998) Characterization of Flavobacterium psychrophilum; comparison of proteolytic activity and virulence of strains isolated from rainbow trout (Oncorhynchus mykiss). In: Barnes AC, Davidson GA, Hiney MP, McIntosh D (eds) Methodology in fish research. Fisheries Research Services, Aberdeen, p 45-52

Madsen L, Dalsgaard I (1999) Reproducible methods for experimental infection with Flavobacterium psychrophilum in rainbow trout Oncorhynchus mykiss. Dis Aquat Org 36: 169-176

Editorial responsibility: David Bruno, Aberdeen, UK
Nematollahi A, Decostere A, Pasmans F, Haesebrouc F (2003a) Flavobacterium psychrophilum infections in salmonid fish. J Fish Dis 26:563-574

Nematollahi A, Decostere A, Pasmans F, Ducatelle R, Haesebrouc F (2003b) Adhesion of high and low virulence Flavobacterium psychrophilum strain to isolated gills arches of rainbow trout Oncorhynchus mykiss. Dis Aquat Org 55:101-107

Noga EJ (1996) Fish disease. Diagnosis and treatment. Mosby-Year Book, St. Louis

OIE (1997) Diagnostic manual for aquatic animal diseases. Office International des Épizooties, Paris

Ostland VE, McGrogan DC, Ferguson HW (1997) Cephalic osteochondritis and necrotic scleritis in intensively reared salmonids associated with Fexibacter psychrophilus. J Fish Dis 20:443-450

Ostland VE, Byrne PJ, Hoover G, Ferguson HW (2000) Necrotic myositis of rainbow trout, Oncorhynchus mykiss (Walbaum): proteolytic characteristics of a crude extracellular preparation from Flavobacterium psychrophilum. J Fish Dis 23:329-336

Otis EJ (1984) Lesions of coldwater disease in steelhead trout (Salmo gairdneri): the role of Cytophaga psychrophila extracellular products. MSc thesis, University of Rhode Island

Pacha RE (1968) Characteristics of Cytophaga psychrophila (Borg) isolated during outbreaks of bacterial cold-water disease. Appl Microbiol 16:97-101

Pate JL, Chang LYE (1979) Evidence that gliding motility in prokaryotic cells is driven by rotary assamblies in the cell envelope. Curr Microbiol 2:59-64

Rangdale RE, Richards RH, Alderman DJ (1997) Colonisation of eyed rainbow trout ova with Flavobacterium psychrophilum leads to rainbow trout fry syndrome in fry. Bull Eur Assoc Fish Pathol 17:108-111

Rangdale RE, Richards RH, Alderman DJ (1999) Histopathological and electron microscopical observations on rainbow trout fry syndrome. Vet Rec 144:251-254

Secades P, Alvarez B, Guijarro JA (2001) Purification and characterization of a psychrophilic, calcium-induced, growth-phase-dependent metalloprotease from the fish pathogen Flavobacterium psychrophilum. Appl Environ Microbiol 67:2436-2444

Shotts EBJ, Starliper CE (1999) Flavobacterial diseases: columnaris disease, cold-water disease and bacterial gill disease. In: Woo PTK, Bruno DW (eds) Fish diseases and disorders, Vol 3. Viral, bacterial and fungal infections. CAB International, Wallingford, p 559-576

Southgate P (1993) Disease in aquaculture. In: Brown L (ed) Aquaculture for veterinarians: fish husbandry and medicine. Pergamon Press, Oxford, p 91-129

Vatsos IN, Thompson KD, Adams A (2001) Adhesion of the fish pathogen Flavobacterium psychrophilum to unfertilized eggs of rainbow trout (Oncorhynchus mykiss) and n-hexadecane. Lett Appl Microbiol 33:178-182

Wood EM, Yasutake WT (1956) Histopathology of fish. III. Peduncle ('coldwater') disease. Prog Fish Cult 18:58-61

Yano $T$ (1996) The nonspecific immune system: humoral defense. In: Iwama G, Nakanishi T (eds) The fish immune system. Organism, pathogen and environment. Academic Press, San Diego, p 106-157

Submitted: October 29, 2003; Accepted: February 4, 2004 Proofs received from author(s): April 1, 2004 